Egyptian Poultry Science Journal

http://www.epsj.journals.ekb.eg/

ISSN: 1110-5623 (Print) - 2090-0570 (Online)

\title{
IMPACT OF SELENIUM SOURCES ON PRODUCTIVE AND PHYSIOLOGICAL PERFORMANCE OF BROILERS A. A-Ghazalah ${ }^{1}$;Abdel-Hamid, A.E ${ }^{2}$;Asmaa M. Abdelaleem ${ }^{2}$ and Asmaa Sh. ELnaggar ${ }^{2}$ \\ 1- Dept. of Anim. Prod.,Fac. of Agric, Cairo Uni.
}

2- Dept. of Anim. and Poult. Prod.,Fac. of Agric., Damanhour Uni.

Corresponding author: Asmaa Sh. Elnaggar; Email: asmaa.elnaggar@agr.dmu.edu.eg Received: $12 / 06 / 2020$ Accepted: $09 / 08 / 2020$

\begin{abstract}
A total number of 210 unsexed (Arbor Acres) broiler chicks at 7 day of age were used to investigate the effects of different sources of Selenium i.e. inorganic (Sodium selenite (SS), organic (Saccharomyces cerevisiae with Se and $\mathrm{Zn} \mathrm{/} \mathrm{Se-}$ Methionine/Se-Glycine/ Se-Yeast and Saccharomyces cerevisiae with $\mathrm{Se}$ ) on the productive performance, blood hematological and biochemical constituents and immune response of broiler chicks. Experimental chicks were randomly divided into seven dietary treatments with six replicate cages per treatment, five chicks each. The first group was fed the basal diet without supplementation (control); while the $2^{\text {nd }}, 3^{\text {rd }}, 4^{\text {th }}$, $5^{\text {th }}, 6^{\text {th }}$ and $7^{\text {th }}$ groups were fed basal diet supplemented with $100 \mathrm{ppm} / \mathrm{kg}$ diet of the above mentioned Se sources, respectively. Results showed that chicks fed the basal diet supplemented with different sources of Se had significantly better BW, BWG and FCR compared with control group. Organic Se supplementation improved growth performance of broilers compared with the inorganic one. Supplementation of different Se sources decreased serum levels of cholesterol and LDL, whereas RBCs count, hemoglobin, PCV, glucose, globulin, thyroid hormones, immune response (IgA- IgM, $\mathrm{IgG}$ ), and antioxidant enzymes activity were significantly increased compared with the control. In conclusion, Se supplementation improved the growth performance, immune response and physiological status of broiler chickens. Broilers fed organic Sesupplemented diets had better growth performance and immune response than those fed inorganic selenium.
\end{abstract}

Key words: Selenium source, Broiler, Performance, Blood parameters, Immune response. 
A. A-Ghazalah ${ }^{1}$ et al.

\begin{tabular}{l}
\hline \multicolumn{3}{c}{ INTRODUCTION } \\
Poultry industry is facing many \\
challenges in the developing world \\
concerning the improvement in \\
production and reproduction (Zia et al., \\
$2017 \mathrm{~b}$ ).
\end{tabular}

Selenium (Se) has been reported as an important essential dietary supplement for improving the bird's performance and health and improvement of meat quality (Haug et al., 2007). Selenium has been recognized as an integral part of over thirty special selenoproteins, Such as glutathione peroxidase enzyme (Zia et al., 2016). It is a constituent of a glutathione peroxidase (GPx), an antioxidant enzyme, which plays an important role for preventing the formation of free radicals. It has been found that there is a significant positive correlation between Se level and GPx activity in most tissues (Madkour et al., 2015 and Zia, et al., 2016). Zhang et al. (2012) found a decrease in GSH-Px activity using low level of $\mathrm{Se}$ in diet. Moreover, $\mathrm{Se}$ is necessary in the diets of poultry to protect them from pancreatic fibrosis and exudative diathesis. Therefore, poultry diets need to supplementary Se to provide a safety margin against deficiency and to maintain better productive performance, ensure health and good meat quality (Deniz et al., 2005 and Göçmen et al., 2016). There are 2 major types of Se in the diet, i.e., organic Se and inorganic. Both, have the positive impact on the performance of poultry, however, organic source (Se-yeast) has found more effective compared to the inorganic source of Se (Mikulski et al., 2009). In this respect, studies showed that Selenoamino acids are absorbed by the same active-transport mechanism used for protein absorption, and therefore more available to the body than inorganic Se sources. In addition, it promotes lower Se excretion in the environment (Pappas et al., 2005 and Wang et al., 2009). Yang et al. (2012) indicates that organic Se had increased growth performance when compared with the inorganic Se. In addition, dietary organic $\mathrm{Se}$ supplementation significantly improved daily gain compared with birds fed diets supplemented with inorganic $\mathrm{Se}$ (Bakhshalinejad et al., 2018). Choupani et al. (2014) and Zia et al. (2017a) found that Se-yeast of grower diets increased the weight of live chickens significantly ( $p$ <0.01). Moreover, Zhou and Wang (2011) indicated an improvement of production performance by organic Se supplementation. Moreover, Ibrahim et al. (2019) found that the groups of broiler chicks supplemented with Se-meth showed an increase in growth performance when compared with sodium selenite (SS). Sundu et al. (2019) indicated that organic Se (Sel-plex) led to an increase in BWG of broiler chickens. Se-yeast has a higher bioavailability when compared with the inorganic Se (Wu et al., 2011 and Ahmad et al., 2012). On the other hand, Zia et al. (2017b) and Meng et al.(2019) studied the mean values of different blood biochemical constituents and found that the increased level of serum total protein, glucose and (GSH-Px) was observed in Se-yeast and in SS fed groups than control.

The dietary prerequisite of poultry for Se regularly can be met by common feedstuffs in the diets, however these feedstuffs vary widely in Se level relying upon the region that they are grown. Consequently, it is a typical practice in poultry production to enhance diets with Se. One of the most widely recognized Se enhancements utilized is sodium selenite (SS), an inorganic source of Se. On the 
other hand, in 2000, the Food and Drug Administration (FDA) approved the utilization of an organic Se source in poultry diets (FDA, 2000). Therefore, the objectives of this research were to compare inorganic and organic $\mathrm{Se}$ sources to assess their effects on productive performance, nutrient digestibility, blood hematological and biochemical constituents, immune response and economic traits of broiler chicks

\section{MATERIALS AND METHODS}

The present study was carried out at the Animal and Poultry Research Centre of the Animal and Poultry Production Department, Faculty of Agriculture (ElBostan Farm), Damanhour University, during the period from October to November 2018. The main objective of the study was to evaluate the effect of dietary supplementation of different sources of selenium (inorganic and organic) on productive performance, blood hematological and biochemical constituents, and immune response of broiler chicks.

\subsection{Chicks and Se supplements}

A total number of 210 unsexed broiler chickens (Arbor Acres) at 7 days of age, obtained from a commercial hatchery were randomly distributed into seven groups, each of five replicates, six birds per replicate. They were reared in similar hygienic and managerial conditions. After the first week, chicks were submitted to seven dietary treatment groups. The first group was fed the basal diet without supplementation (control); while the $2^{\text {nd }}$, $3^{\text {rd }}, 4^{\text {th }}, 5^{\text {th }}, 6^{\text {th }}$ and $7^{\text {th }}$ groups were fed basal diet supplemented with $100 \mathrm{ppm} / \mathrm{kg}$ diet of Se-inorganic (S.S), Saccharomyces cerevisiae with $\mathrm{Se}$ and $\mathrm{Zn}$, Se-Meth, Se-Glycine, Se-Yeast and Saccharomyces cerevisiae with Se (S.C), respectively. The experimental diets were formulated according to the strain management guide as shown in Table 1 .

\subsection{Housing and husbandry}

Chicks were housed in breeding pens in semi-opened house. They were fed, ad libitum, the experimental diets and given free access to water. A light schedule similar to commercial condition was $23 \mathrm{~h}$ light until $7^{\text {th }}$ day followed by $20 \mathrm{~h}$ light from the $8^{\text {th }}$ day until the end of the experimental period was provided. Average outdoor minimum and maximum temperature and relative humidity during the experimental period was $20 \mathrm{C}^{\circ}$ and 27 $\mathrm{C}^{\mathrm{o}}$ and $55.7 \%$ and $58.7 \%$, respectively. The brooding temperature (indoor) was declined gradually, being 32, 30, 27 and 24-21 $\mathrm{C}^{\mathrm{o}}$ during 1-7, 8-14, 15-20 and 2135 days of age, respectively.

\subsection{Data collection:}

Performance parameters including individual live body weight (LBW, g) and feed intake (FI, g) were recorded weekly throughout the trial period (7-35 $\mathrm{d}$ of age). For each replicate within treatment groups, body weight gain (BWG, g) and feed conversion ratio (FCR) was estimated.

Apparent digestibility of dry matter, crude protein, ether extract and crude fiber were done using five birds per treatment housed individually in metabolic cages using total collection method as cited by Abou-Raya and Galal (1971). Nitrogen, ether extract, crude fiber and dry matter of the excreta as well as those of feed were determined according to AOAC (2004). Economical evaluation for all experimental treatment diets was made according to Zeweil, (1996). At 35 d of age, serum samples were collected from three birds per each treatment to determine some blood constituents in terms of glucose 


\section{A. A-Ghazalah ${ }^{\mathbf{1}}$ et al.}

concentration $(\mathrm{mg} / \mathrm{dl})$ according to Trinder (1969), total protein (Henry et al., 1974), albumin (Doumas, 1971), globulin and its fractions ( $\alpha$-globulin, $\beta$-globulin and $\gamma$-globulin) according to Bossuyt et al. (2003). In addition, serum samples were assigned for determination of creatinine and uric acid (Bartles et al., 1972), total cholesterol (Stein, 1986), triglycerides (Fossati and Prencipe, 1982), while LDL was determined according to Friedewald et al.(1972) and HDL according to (Lopez-Virella, 1977). The activity of serum aspartate amino transferase, and serum alanine amino transferase, were estimated according to Reitman and Frankle (1957).

Besides, six blood samples were collected from each treatment in heparinized tubes to determine the number of red blood cells, white blood cells and different types of leukocytes. Packed cell volume (\%), Hemoglobin concentration and red cell indices ( $\mathrm{MCH}$ and $\mathrm{MCHC})$ were determined according to the following equations:

Mean Corpuscular Hemoglobin $\quad(\mathrm{MCH}$, $\mathrm{Pg})=\mathrm{HbX} 10 /$ Red blood cell

Mean Corpuscular Hemoglobin Concentration $(\mathrm{MCHC}, \mathrm{g} / \mathrm{dl})=\mathrm{HbX} 100 /$ Packed cell volume.

Total antioxidant capacity was determined according to Koracevic et al. (2001), Superoxide dismutase activity (Misra and Fridovich, 1972), Glutathione peroxidase activity (Paglia and Valentine, 1967) and Glutathione concentration (Ellman, 1959).Phagocytic activity and index were determined according to Kawahara et al. (1991). Phagocytic activity (PA) $=$ Percentage of phagocytic cells containing yeast cells. Phagocytic index $(\mathrm{PI})=$ Number of yeast cell phagocytized/ Number of phagocytic cells.
Alkaline phosphatase (ALP) activity was determined according to the colorimetric method of Bauer et al.(1982). Serum immunoglobulins (IgY, $\operatorname{IgM}$ and $\operatorname{Ig} \mathrm{A}$ ) were determined using commercial ELISA kits (Kamiya Biomedical Company, USA) according to Bianchi et al. (1995). Lymphocyte transformation test was determined following the method described by Balhaa et al. (1985). Serum bactericidal activity to Aeromonas hydrophila strain was determined according to Rainger and Rowley (1993). Serum lysozyme activity was measured with the turbidimetric method described by Engstad et al. (1992) and the results are expressed as one unit of lysozyme activity that defined as a reduction in absorbance at $0.001 / \mathrm{min}$. Lysozyme activity $=(\mathrm{A} 0-\mathrm{A}) / \mathrm{A}$.

All measurements were conducted according to the manufacturer's instructions.

\subsection{Statistical analysis}

Data were analyzed by the GLM procedure (Statistical Analysis System (SAS),2002) using one-way ANOVA with the following model: $Y i j k=\mu+\mathrm{Ti}+$ eijk, Where :

$\mathrm{Y}$ is the dependent variable; $\mu$ is the general mean; $\mathrm{T}$ is the effect of experimental treatments; $e$ is the experimental random error.

Noting that before analysis, all percentages were subjected to logarithmic transformation $\left(\log _{10} x+1\right)$ to normalize data distribution. The differences among means were determined using Duncan's new multiple range test (Duncan,1955) at $\mathrm{P}<0.05$.

\section{Results and Discussion}

\subsection{The performance traits:}

The growth performance of broilers that fed diets supplemented with different sources of Se during 7 to $35 \mathrm{~d}$ of age are shown in Table 2. Initial BW of broiler 
chicks was similar for all treatments. Chicks fed diets supplemented with either Se-organic or Se-inorganic significantly recorded higher BW compared to control diet (basal diet) at $35 \mathrm{~d}$ of age. Moreover, broiler chicks fed diet with Se-Meth, SeGlycine, Se-Yeast and SC with Se had significantly greater BWG during 7-35 d of age. In general, organic $\mathrm{Se}$ supplementation has improved BWG of broilers during the whole experiment period (7-35 d of age). Results indicated that organic-Se increased FI of broiler during period compared with inorganicSe and control group. Therefore, chicks having either Se-organic or Se-inorganic had significantly better FCR compared to control diet (basal diet) all over the experimental period. Among the experimental groups, the diet with SeMeth, Se-Yeast and SC with Se had significantly better FI followed by those fed diet with Se-Glycine, SC with Se-Zn and Se-inorganic compared to the control group. Therefore, chicks fed basal diet supplemented with different sources of $\mathrm{Se}$ had significantly better economic efficiency than the control group. Moreover, organic Se supplementation improved economic efficiency compared with inorganic Se and control. The positive effect of $\mathrm{Se}$ on $\mathrm{BW}$ of treated groups could be attributed to the role of Se in body metabolism and growth, since it has been shown to create an integral part of the deiodinases (Zhang et al.,2011), where the iodothyronine deiodinases enzymes convert the prohormone T4 to T3 being the active form (Chun et al.,2009) which is significant for normal growth and development in birds (Ankur and Baghel,2011). Also, T3 hormone is a main hormone which regulates growth by dominating the body's energy and protein anabolism (Preter,2000).

The obtained results are in agreement with those of Sevcikova et al. (2006) who found that organic Se supplementation improved growth performance of broiler chicken compared with the inorganic Se. Upton et al. (2008) indicated that BW of broilers significantly increased when they were given diets with $0.2 \mathrm{mg} / \mathrm{kg}$ of organic Se compared with those given diet with inorganic $\mathrm{Se}$ in addition to the control diet. Zhou and Wang (2011) indicated an improvement of production performance by organic $\mathrm{Se}$ supplementation. Also, Yang et al. (2012) indicates that organic $\mathrm{Se}$ had increased growth performance when compared with the inorganic Se. In addition, dietary organic Se supplementation significantly improved daily gain compared with birds fed diets supplemented with inorganic $\mathrm{Se}$ (Bakhshalinejad et al., 2018). In this respect, Sundu et al. (2019) indicated that organic Se (Sel-plex) led to an increase in BWG of broiler chickens. Moreover, it has been reported that BW improved in chicken reared under the heat stress by using diet supplemented with Se (Niu et al., 2009 and Ibrahim et al., 2011). Such improvement may be due to the fact that organic $\mathrm{Se}$ is more bioavailable than inorganic Se (Edens et al., 2001) which obviously resulted in enhanced BW. Similarly, it is claimed that increased BW is linked to using organic Se in the diet of broilers (Salman et al., 2007).

On the other hand, several researchers reported that Se supplementation did not influence $(\mathrm{P}>0.05)$ the growth performance of broiler chickens during the experimental period (Wang et al., 2011; Ahmad et al., 2012; Chen et al., 2013; Rao et al., 2013; Li et al., 2017 and 


\section{A. A-Ghazalah ${ }^{\mathbf{1}}$ et al.}

Bakhshalinejad et al., 2019).The reason for the contradiction among the results might be due to the result of the difference in the species used, age of birds, duration and the amount of $\mathrm{Se}$ added to the diet.

\subsection{Apparent digestibility of nutrients:}

Data concerning the effects of $\mathrm{Se}$ source on the apparent digestibility of the nutrients of broilers are shown in Table 3. Basal diet supplemented with both of Seorganic and Se-inorganic significantly increased the digestibility of crude protein (CP) compared to control diet (basal diet). Basal diet supplemented with Se-organic significantly increased the ether extract compared to control diet (basal diet). However, there were no significant effects of different Se sources on crude fiber $(\mathrm{CF})$ digestibility. Broiler fed diet with Se-Meth, Se-Glycine, SeYeast and SC with Se had significantly greater dry matter (DM) digestibility followed by those fed basal diet supplemented with SC-Se.Zn in addition to the Se-inorganic compared to the control. These results are in consistent with Edens (2001) who indicated that Selplex supplementation in the diet increased DM digestibility of the diets fed to broiler chickens. The authors also found that DM digestibility of the diets increased from 74.4 to $82.4 \%$.On the other hand, Amer et al. (2018) showed insignificant differences on digestion coefficient for $\mathrm{DM}, \mathrm{OM}$, and CP between the Se treated groups and control group. Also, no significant differences in the digestion coefficient of $\mathrm{DM}, \mathrm{OM}$, and $\mathrm{CP}$ were observed between the organic and inorganic source of Se. In this connection, Sundu et al. (2019) reported that there was no increase in DM digestibility when the diets were supplemented with Se from different sources.

\subsection{The blood hematological criteria:}

The blood hematological criteria of broilers fed diet supplemented with different Se sources at 35 day of age are shown in Table 4 . Chicks fed basal diet supplemented with Se-organic and $\mathrm{Se}$ inorganic had significantly better RBC's, $\mathrm{Hb}$ and $\mathrm{PCV}$ compared to the control group. The basal diet supplemented with either Se-organic or Se-inorganic significantly increased the percentage of lymphocytes compared to control diet. There were no significant differences in White blood cells WBC's differential leukocytes counts between different sources of Se, however, the differences were significant compared to the control. In this connection, El-Sheikh et al. (2010) showed that overall means of blood hemoglobin (Hb), RBC's and WBC's were increased in chicken fed diets with Se compared with those fed control diet. ElSebai (2000) and Abaza (2002) found that WBC's or RBC's counts increased by using Se supplementation to diets of chickens. Organic Se play important role for increasing number of lymphocytes therefore improve immune system (Fisinin et al., 2008). Moreover, Hanafy et al. (2009) found that Se supplementation increased values of $\mathrm{Hb}$, RBC's and WBC's in Se groups compared with those in the control group. While, Boostani et al.,(2015) found that dietary Se supplementation (organic or Inorganic) had no significant effect on $\mathrm{Hb}$, RBC's and WBC's in broiler chickens. The reason for the contradiction among the results might be due to the difference in the species used, age of animals, duration and the amount of $\mathrm{Se}$ addition to the diet. 
Selenium source, Broiler, Performance, Blood parameters, Immune response

\subsection{Biochemical constituents of blood: \\ 3.4.1. Protein profile, glucose and thyroid hormones:}

The blood serum proteins of broiler fed diet supplemented with different sources of Se at 35 day of age are shown in Table 5. Organic Se supplementation group gave significantly higher total protein than the other groups. Moreover, Se-organic supplementation significantly decreased globulin. Also, broiler fed basal diet supplemented with Se Meth, Se-Glycine, Se-yeast and S.C with Se had significantly greater $\alpha-$ globulin, $\beta-$ globulin, $\gamma$-Globulin followed by those fed diet with S.C, Se$\mathrm{Zn}$ and Se-inorganic compared to the control group. In this connection, Ramezani et al. (2011) reported that increased total protein of blood $(\mathrm{P} \leq 0.05)$ was observed because using $\mathrm{Se}$ supplementation. Also, there was increase in the blood protein, globulin and albumin due to overall effect of $0.1 \mathrm{ppm}$ Se and the values are $466 \mathrm{~g} / \mathrm{dl}, 1.66 \mathrm{~g} / \mathrm{dl}$, $3.00 \mathrm{~g} / \mathrm{dl}$ and 0.56 , respectively (Naik, 2012). Also, El-Deep et al. (2017) showed that total protein was increased by dietary all types of Se source. Attia et al. (2010) found that Se supplementation significantly decreased albumin and globulin on layer. On the other hand, Yang et al. (2012) found that the total protein, globulin and glucose concentration were observed to be insignificant when compared between $\mathrm{Se}$ supplemented and control group in chicks. Inorganic or organic Se supplementation increased serum glutathione peroxidase concentration $(\mathrm{P}<0.05)$ but, did not affect blood total protein and albumin, with respect to control (Invernizzi et al., 2013).

Serum content of glucose and thyroid hormones of broiler fed diet with $\mathrm{Se}$ supplementation at 35 day of age are shown in Table 5. Organic Se supplementation increased glucose than the control group, while, $\mathrm{T}_{3}$ and $\mathrm{T}_{4}$ concentrations were significantly higher in all Se sources compared to the control. Also, Se-Meth, Se-Glycine and Se-Yeast and S.C with Se supplementation groups gave significantly higher $\mathrm{T}_{3}$ concentrations than other treated groups and the control. Similarly, Zia et al. (2017b) demonstrates that the increased $(\mathrm{P} \leq 0.05)$ level of glucose was observed in Se-yeast and in SS fed groups than control. Also, Upton et al. (2008) found that serum T3 level was higher in chickens fed diet with Sel-Plex ${ }^{\mathrm{TM}}$ compared to those fed a basal diet. Also, Choct et al. (2004) and Upton et al. (2008) reported that serum T3 concentration was higher in broiler chickens supplemented with Sel-Plex ${ }^{\mathrm{TM}}$ compared to those in birds fed a basal diet. In addition, Srimongkol (2003) and Choupani et al., (2014) reported that Se supplementation increased T3 than in the unsupplemented control group. El-Sheikh et al. (2010) also showed that overall means of T3 were significantly increased in Se treated groups than the control group of chicken.

\subsubsection{Renal and liver function tests:}

Data concerning the effects of Se sources on renal and liver functional of broiler fed diet with different sources of Se at 35 day of age are shown in Table 5 .Additions of organic and inorganic sources of $\mathrm{Se}$ to the feed had a significantly lower ALT in blood plasma compared with the control group. While, AST was significantly lower in Seorganic groups than the control group. Also, S.C with Se supplementation group gave significantly lower Uric acid concentrations in plasma than the other 


\section{A. A-Ghazalah ${ }^{\mathbf{1}}$ et al.}

Se supplementation group compared with the control group. However, there was no significant effect of the different sources of $\mathrm{Se}$ supplementation on ALT/AST, Creatinine, Uric acid and alkaline phosphatase in blood serum. The present results are in agreement with those obtained by Peric et al. (2009) demonstrating that the levels of ALT and AST were decreased with the supplementation of Se. Decreased level of ALT and AST and creatinine values were noted in the birds exposed to Se-yeast supplemented diet in contrast to SS treated or those fed control diet (Zia et al., 2017b). Also, Yang et al. (2012) found that the AST, alkaline phosphatase and urea concentrations were observed to be insignificant when compared between Se supplemented and control group in chicks. On the other hand, Selim et al. (2015) and Ibrahim et al. (2019) showed that the activity of liver enzymes of Ross broiler chickens including ALT and AST were not significantly affected by the interaction between different sources of Se. In addition, Yang et al. (2012) observed that Se (organic or inorganic) didn't affected liver enzymes. Moreover, Inorganic and organic Se supplementation did not affect ALT and AST activity or the serum antioxidant capacity of turkey (Mikulski et al., 2009).

\subsubsection{Lipids profile:}

Data concerning the effects of Se sources on the blood serum lipid profile of broiler at 35 day of age are shown in Table 5. Additions of organic and inorganic sources of Se to the feed had a significantly lowers, cholesterol and triglycerides in blood serum compared with the control group. In addition, chicks fed basal diet supplemented with Se-Glycine had significantly the lowest low-density lipoprotein (LDL). On the other hand, there was no significant effect of the different sources of $\mathrm{Se}$ supplementation on the high-density lipoprotein (HDL) in blood. Similarly, Yang et al. (2012) revealed that the HDL concentration were observed to be insignificant when compared between Se supplemented and control group in chicks. Data obtained herein confirmed those obtained by Ferit et al. (2003) that cholesterol levels reduced as a result of Se supplementation. In addition, Ljubic et al. (2006) found that the organic Se supplementation decreasing the total cholesterol level during the fattening period and increasing the free cholesterol level after $48 \mathrm{~h}$ feed deprivation. Also, decreased triglycerides levels has been observed as a result of $\mathrm{Se}$ addition (Ramezani et al., 2011). Also, it has been reported that Se addition lowered the total cholesterol in blood serum (Attia et al., 2010 and Bunglavan et al., 2014). However, Zia et al. (2017b) found that serum triglycerides level in the birds received Se-yeast added diet was enhanced compared to those got inorganic Se-treated or control diet. Moreover, Yang et al. (2012) and Invernizzi et al. (2013) revealed that total cholesterol and triglycerides concentrations were observed to be insignificant when compared between Se supplemented and control group in chicks.

\subsubsection{Antioxidative defense indicators:}

The blood serum antioxidant enzymes of broiler fed diet supplemented with different sources of Se at 35 day of age are shown in Table 6 .Chicks fed basal diet supplemented organic $\mathrm{Se}$ groups significantly increased superoxide dismutase (SOD) activity and GSH concentration compared with those fed inorganic $\mathrm{Se}$ and control group. 
However, there were no significant effects among inorganic Se and organic Se groups in GPX activity. Moreover, broilers fed basal diet supplemented with either Se-organic or Se-inorganic sources had significantly higher TAOC activity and lower Malondialdehyde (MDA) values compared with those fed the control diet. Our findings on GSH-Px are in agreement with Yoon et al. (2007); Wang and $\mathrm{Xu}$ (2008) and Ebeid et al. (2013) who showed that dietary Se supplementation improves antioxidant status by activating GSH-Px. Also. Se supplementation could significantly improve blood glutathione peroxidase activity and enhance oxidation resistance of broilers (Cai et al., 2012; Oliveira et $a l ., 2014)$. In this respect, Gajčević et al. (2009), Dalto et al. (2015) indicated that GPX activity increased by using the Sesupplements. Also, the serum GSH-Px activity was significantly increased when Se was supplemented to the control diet (Invernizzi et al., 2013). Okunlola et al. (2015) also noted that GPx activity increased with both organic and inorganic supplements of Se. It has been found by Chen et al. (2013) that supplementation with $0.3 \mathrm{mg} / \mathrm{kg}$ Se-yeast led to increased GSH-Px and SOD activities in serum relative to $0.3 \mathrm{mg} / \mathrm{kg}$ SS supplementation. Moreover, Bakhshalinejad et al., (2018) showed that the GSH-Px and TAC were improved by using supplementation with organic Se sources. In addition, Moslehi et al. (2019) observed that glutathione peroxidase activity was increased by supplementation of $\mathrm{Se}$ (organic and inorganic). Also Birds fed Se-yeast had increased TAOC compared with birds that had not received supplemental Se $(\mathrm{P}<0.01)$. In contrast to the results obtained, there were no significant differences among Se sources or levels in
GPX3 activity (Payne and Southern, 2005a,b) and SOD activity (Moslehi et al., 2019). Moreover, D-Se-meth supplementation was more effective ( $p<0.01)$ in increasing blood GSH level and decreasing breast muscle malondialdehyde (MDA) level than SS. The GSH-Px were improved by using supplementation of organic Se sources (Bakhshalinejad et al., 2018).

\subsubsection{Immune response indices:}

The blood serum Immune indices of broiler fed diets supplemented with different sources of Se at 35 day of age are shown in Table 7.

Feeding broiler basal diet supplemented with Se-organic and Se-inorganic significantly increased P.A, B.A, and IgM compared with those fed the control diet. Chicks fed basal diet supplemented with Se-organic groups significantly increased P.I, L.T.T, L.A and $\operatorname{IgG}$ in blood compared with those fed the control diet. In addition, the highest IgA was in broiler fed Se-Meth and Se-Glycine followed by those fed basal diet supplemented with SC with Se, SC with $\mathrm{Se}-\mathrm{Zn}$, Se-Yeast and Se-inorganic compared to the control group. In this study, $\operatorname{IgM}$ and $\operatorname{IgG}$ concentrations in response to anti-sheep red blood cell (SRBC) were significantly higher in groups with organic Se than those having the inorganic Se as well as the control diet. In this respect, dietary organic Se supplementation increased total antiSRBC and IgG titres (Cai et al., 2012 and Zamani Moghaddam et al., 2017). Moslehi et al., (2019) showed that IgM was greater in hens fed diets containing $\mathrm{SS}$ and Se-yeast than those fed control diet $(\mathrm{P}<0.05)$. Madron and Vrzgulova (1988) found that $\mathrm{Se}$ supplementation improved the immune system and raised the natural resistant of animals by 


\section{A. A-Ghazalah ${ }^{1}$ et al.}

increasing response of the organism to antigenic stimuli. Also, Hegazy and Adachi (2000), Schrauzer (2000) and DengHua et al. (2001) reported an increase in humoral antibody titers by using Se in feed, the perceptible reason for improved antibody production is the increase in number of lymphocytes with increased Se supplementation. Moreover, Boostani et al. (2015) found that the highest serum IgM levels were observed for unstressed birds which given organic Se. Besides, organic Se supplementation led to better production performance and immune response than the inorganic one (Bakhshalinejad et al., 2018).

Table (1): Composition and calculated analysis of experimental diets fed to broiler chicks from 7 to 35 days of age.

\begin{tabular}{|c|c|c|}
\hline Ingredients (\%) & $\begin{array}{l}\text { Starter diet } \\
\text { ( } 7 \text { to } 21 \text { d of age) }\end{array}$ & $\begin{array}{l}\text { Growing diet } \\
\text { ( } 22 \text { to } 35 \mathrm{~d} \text { of age) }\end{array}$ \\
\hline Yellow Corn & 57.60 & 61.00 \\
\hline Soybean Meal (48\%) & 29.50 & 26.00 \\
\hline Corn gluten meal $(60 \%)$ & 5.20 & 6.00 \\
\hline Soy oil & 1.10 & 2.70 \\
\hline Full fat soya bean & 2.00 & 0.00 \\
\hline Mono calcium Phosphate & 1.50 & 1.65 \\
\hline Lime stone & 1.90 & 1.50 \\
\hline Choline chloride & 0.10 & 0.10 \\
\hline Sodium Bicarbonate & 0.20 & 0.20 \\
\hline Salt $(\mathrm{Na} \mathrm{Cl})$ & 0.20 & 0.20 \\
\hline $\mathrm{DL}$-methionine & 0.10 & 0.10 \\
\hline L-lysine $\mathrm{HCl}$ & 0.30 & 0.25 \\
\hline Broiler Premix * & 0.30 & 0.30 \\
\hline Total & 100 & 100 \\
\hline \multicolumn{3}{|c|}{ Calculated analysis (on DM basis) ${ }^{* * * *}$} \\
\hline Crude Protein, \% & 22.9 & 21.4 \\
\hline $\mathrm{ME}(\mathrm{kcal} / \mathrm{kg}) * *$ & 3042 & 3147 \\
\hline Ether extract, $\%$ & 4.10 & 4.40 \\
\hline Calcium, \% & 1.05 & 0.90 \\
\hline Available phosphorus, $\%$ & 0.51 & 0.43 \\
\hline Methionine, $\%$ & 0.50 & 0.46 \\
\hline Lysine, \% & 1.40 & 1.23 \\
\hline Methionine + Cystine, $\%$ & 0.98 & 0.89 \\
\hline
\end{tabular}

* Each kg premix contains: vit. A (12 I.U.), vit. D3 (5 I.U.), vit. E (75 I.U.), vit. K menadione (2 $\mathrm{mg})$, vit. B1 (2 mg), vit. B2 (6 mg), vit. B6 (4 mg), vit. B12 (0.016 mg), Pantathenic acid (13 $\mathrm{mg}$ ), Nicotinic acid (55 mg), Folic acid (2 mg), Biotin (0.2 mg), Copper (16 mg), Iodine (1.25 $\mathrm{mg}$ ), Iron (40 mg), Manganese (120 mg), Zinc (100 mg), Selenium (0.3 mg).

** ME=Metabolizable Energy $\quad * * *$ According to NRC(1994) 
Table (2): Effect of different selenium sources on the performance and economical efficiency of broiler chicks.

\begin{tabular}{|l|c|c|c|c|c|c|c|c|c|}
\hline Treatment & Control & S.S & $\begin{array}{c}\text { SC- } \\
\text { Se.Zn }\end{array}$ & $\begin{array}{c}\text { Se- } \\
\text { Meth }\end{array}$ & $\begin{array}{c}\text { Se- } \\
\text { Glycine }\end{array}$ & $\begin{array}{c}\text { Se- } \\
\text { Yeast }\end{array}$ & SC & SEM & $\begin{array}{c}P \\
\text { value }\end{array}$ \\
\hline B.W 7d & 173 & 171 & 162 & 166 & 168 & 173 & 171 & 3.95 & NS \\
B.W 35d & $1666^{\mathrm{b}}$ & $1789^{\mathrm{ab}}$ & $1867^{\mathrm{ab}}$ & $2000^{\mathrm{a}}$ & $1994^{\mathrm{a}}$ & $1940^{\mathrm{a}}$ & $1950^{\mathrm{a}}$ & 46.01 & 0.001 \\
B.W.G 7- 35 d & $1493^{\mathrm{c}}$ & $1620^{\mathrm{b}}$ & $1706^{\mathrm{b}}$ & $1834^{\mathrm{a}}$ & $1826^{\mathrm{a}}$ & $1830^{\mathrm{a}}$ & $1830^{\mathrm{a}}$ & 467 & 0.001 \\
FI 7-35 & $3267^{\mathrm{a}}$ & $2996^{\mathrm{b}}$ & $2888^{\mathrm{c}}$ & $2775^{\mathrm{c}}$ & $2784^{\mathrm{c}}$ & $2811^{\mathrm{c}}$ & $2874^{\mathrm{c}}$ & 18.25 & 0.002 \\
FCR7-35 & $2.17^{\mathrm{a}}$ & $1.85^{\mathrm{b}}$ & $1.69^{\mathrm{bc}}$ & $1.51^{\mathrm{c}}$ & $1.52^{\mathrm{c}}$ & $1.53^{\mathrm{c}}$ & $1.57^{\mathrm{c}}$ & 0.053 & 0.001 \\
Total cost (L.E) & $16.3^{\mathrm{a}}$ & $14.93^{\mathrm{b}}$ & $14.45^{\mathrm{b}}$ & $13.90^{\mathrm{c}}$ & $13.1^{\mathrm{c}}$ & $14.1^{\mathrm{b}}$ & $14.4^{\mathrm{b}}$ & 0.449 & 0.001 \\
Total revenue (L.E) & 31.7 & 33.9 & 35.5 & 38.2 & 38.1 & 39.2 & 37.3 & 0.784 & 0.062 \\
EE & $0.945^{\mathrm{c}}$ & $1.20^{\mathrm{b}}$ & $1.34^{\mathrm{a}}$ & $1.37^{\mathrm{a}}$ & $1.37^{\mathrm{a}}$ & $1.38^{\mathrm{a}}$ & $1.36^{\mathrm{a}}$ & 4.43 & 0.002 \\
REE (\%) & $100^{\mathrm{c}}$ & $139^{\mathrm{b}}$ & $141^{\mathrm{a}}$ & $144^{\mathrm{a}}$ & $144^{\mathrm{a}}$ & $146^{\mathrm{a}}$ & $143^{\mathrm{a}}$ & -- & -- \\
\hline
\end{tabular}

${ }^{a, b, c}$ Means in the same row followed by different letters are significantly different at $p \leq 0.05$.SEM=Standard error of mean's. S .C = Saccharomyces cerevisiae with Se; S .S =Sodium Selenite; B.W= Body weight,.B.W.G= Body weight gain, $\mathrm{FI}=$ Feed intake, $\mathrm{FCR}=$ feed conversion ratio.

$\mathrm{EE}=$ Economical efficiency $; \mathrm{REE}=$ Relative economical efficiency ]

Table (3): Effect of different selenium sources on the apparent digestibility of the nutrients $(\%)$

\begin{tabular}{|l|c|c|c|c|c|c|c|c|c|}
\hline Treatment & Control & S.S & $\begin{array}{c}\text { SC- } \\
\text { Se.Zn }\end{array}$ & $\begin{array}{c}\text { Se- } \\
\text { Meth }\end{array}$ & $\begin{array}{c}\text { Se- } \\
\text { Glycine }\end{array}$ & Se-yeast & SC & SEM & P value \\
\hline Crude protein & $66.11^{\mathrm{b}}$ & $70.1^{\mathrm{a}}$ & $73.4^{\mathrm{a}}$ & $75.1^{\mathrm{a}}$ & $79.9^{\mathrm{a}}$ & $80.9^{\mathrm{a}}$ & $81.0^{\mathrm{a}}$ & 2.18 & 0.005 \\
Ether extract & $69.5^{\mathrm{b}}$ & $63.4^{\mathrm{b}}$ & $70.1^{\mathrm{a}}$ & $75.9^{\mathrm{a}}$ & $80.3^{\mathrm{a}}$ & $81.3^{\mathrm{a}}$ & $83.1^{\mathrm{a}}$ & 9.19 & 0.001 \\
Crude fiber & $17.1^{\mathrm{a}}$ & 18.6 & $19.3^{\mathrm{b}}$ & 17.9 & 19.8 & 18.6 & 20.1 & 1.09 & 0.098 \\
Dry matter & $66.9^{\mathrm{c}}$ & $72.2^{\mathrm{b}}$ & $70.8^{\mathrm{b}}$ & $76.5^{\mathrm{a}}$ & $75.9^{\mathrm{a}}$ & $78.9^{\mathrm{a}}$ & $76.5^{\mathrm{a}}$ & 8.77 & 0.002 \\
\hline
\end{tabular}

a,b,c Means in the same row followed by different letters are significantly different at $\mathrm{p} \leq 0.05 \mathrm{SEM}=\mathrm{Standard}$ error of mean's. S .C = Saccharomyces cerevisiae with Se; S .S =Sodium Selenite. 


\section{A. A-Ghazalah ${ }^{1}$ et al.}

Table (4): Effect of different Selenium sources on hematological criteria of broiler chicks fed different sources of Se.

\begin{tabular}{|c|c|c|c|c|c|c|c|c|c|}
\hline Treatment & Control & S.S & $\begin{array}{c}\text { SC- } \\
\text { Se.Zn }\end{array}$ & $\begin{array}{c}\text { Se- } \\
\text { Meth }\end{array}$ & $\begin{array}{c}\text { Se- } \\
\text { Glycine }\end{array}$ & $\begin{array}{c}\text { Se- } \\
\text { yeast }\end{array}$ & SC & SEM & $P$ value \\
\hline RBC's $\left(10^{6} / \mathrm{cmm} 3\right)$ & $3.13^{\mathrm{b}}$ & $3.99^{\mathrm{ab}}$ & $4.53^{\mathrm{a}}$ & $4.46^{\mathrm{a}}$ & $4.36^{\mathrm{a}}$ & $4.31^{\mathrm{a}}$ & $4.23^{\mathrm{a}}$ & 0.501 & 0.001 \\
\hline $\mathrm{Hb}(\mathrm{g} / 100 \mathrm{ml})$ & $9.33^{\mathrm{b}}$ & $11.6^{\mathrm{ab}}$ & $12.6^{\mathrm{a}}$ & $12.3^{\mathrm{a}}$ & $13.0^{\mathrm{a}}$ & $12.3^{\mathrm{a}}$ & $12.0^{\mathrm{a}}$ & 0.602 & 0.002 \\
\hline PCV \% & $23.6^{\mathrm{b}}$ & $30.3^{\mathrm{ab}}$ & $36.3^{\mathrm{a}}$ & $35.0^{\mathrm{a}}$ & $37.0^{\mathrm{a}}$ & $36.6^{\mathrm{a}}$ & $34.3^{\mathrm{a}}$ & 2.22 & 0.01 \\
\hline WBC's $\left(10^{3} / \mathrm{mm}^{3}\right)$ & 24.6 & 28.3 & 28.3 & 26.0 & 27.0 & 26.3 & 27.6 & 0.671 & NS \\
\hline Lymphocytes (\%) & $40.6^{\mathrm{b}}$ & $45.3^{\mathrm{a}}$ & $45.3^{\mathrm{a}}$ & $43.0^{\mathrm{a}}$ & $45.0^{\mathrm{a}}$ & $46.0^{\mathrm{a}}$ & $44.3^{\mathrm{a}}$ & 0.791 & 0.002 \\
\hline Monocytes (\%) & 16.6 & 16.0 & 16.0 & 16.3 & 16.0 & 16.33 & 16.00 & 0.482 & NS \\
\hline Eosinophils, (\%) & 0.660 & 0.330 & 0.330 & 0.330 & 0.660 & 1.00 & 0.990 & 0.273 & NS \\
\hline Heterophils, (\%) & 13.6 & 12.6 & 12.6 & 13.3 & 14.0 & 13.0 & 11.6 & 0.715 & NS \\
\hline Basophils, (\%) & 23.6 & 24.0 & 24.0 & 23.6 & 24.0 & 22.6 & 22.3 & 0.667 & NS \\
\hline
\end{tabular}

a,b,c Means in the same row followed by different letters are significantly different at $\mathrm{p} \leq 0.05$.SEM=Standard error of mean's. S .C = Saccharomyces cerevisiae with Se; S .S =Sodium Selenite; RBC's, red blood cell; PCV, packed cell volume; $\mathrm{MCH}$, mean corpuscular hemoglobin; MCV, Mean cell volume, MCHC, Mean Corpuscular Hemoglobin Concentration

Tble (5): Effect of different selenium sources on blood biochemical criteria of broiler chicks.

\begin{tabular}{|c|c|c|c|c|c|c|c|c|c|}
\hline Treatment & Control & S.S & $\begin{array}{c}\text { SC- } \\
\text { Se.Zn }\end{array}$ & $\begin{array}{c}\text { Se- } \\
\text { Meth }\end{array}$ & $\begin{array}{c}\text { Se- } \\
\text { Glycine }\end{array}$ & $\begin{array}{c}\text { Se- } \\
\text { Yeast }\end{array}$ & SC & SEM & $\begin{array}{c}P \\
\text { value }\end{array}$ \\
\hline Total Protein(mg/dl) & $3.40^{\mathrm{b}}$ & $4.17^{b}$ & $5.27^{\mathrm{a}}$ & $4.97^{\mathrm{a}}$ & $4.87^{\mathrm{a}}$ & $4.75^{\mathrm{a}}$ & $4.96^{\mathrm{a}}$ & 0.191 & .001 \\
\hline Albumin(mg/dl) & 1.50 & 1.34 & 1.76 & 1.44 & 1.43 & 1.35 & 1.51 & 0.092 & 0.002 \\
\hline Globulin(mg/dl) & $1.90^{\mathrm{b}}$ & $2.81^{\mathrm{b}}$ & $3.51^{\mathrm{a}}$ & $3.53^{\mathrm{a}}$ & $3.44^{\mathrm{a}}$ & $3.40^{\mathrm{a}}$ & $3.45^{\mathrm{a}}$ & 0.165 & 0.001 \\
\hline$\alpha-$ globu & $0.830^{\mathrm{c}}$ & $1.13^{\mathrm{b}}$ & $1.19^{\mathrm{b}}$ & $1.39^{\mathrm{a}}$ & $1.29^{\mathrm{a}}$ & $1.31^{\mathrm{a}}$ & $1.28^{\mathrm{a}}$ & 0.021 & 0.003 \\
\hline$\beta$-globulin (g/dl) & $0.867^{\mathrm{c}}$ & $1.11^{\mathrm{b}}$ & $1.16^{\mathrm{b}}$ & $1.29^{\mathrm{a}}$ & $1.30^{\mathrm{a}}$ & $1.26^{\mathrm{a}}$ & $1.31^{\mathrm{a}}$ & 0.041 & 0.002 \\
\hline$\gamma$-Globulin (g/dl) & $0.349^{c}$ & $0.565^{\mathrm{b}}$ & $0.691^{\mathrm{b}}$ & $0.855^{\mathrm{a}}$ & $0.844^{\mathrm{a}}$ & $0.837^{\mathrm{a}}$ & $0.860^{\mathrm{a}}$ & 0.066 & 0.001 \\
\hline Glucose(mg/dl) & $180^{\mathrm{b}}$ & $188^{\mathrm{ab}}$ & $227^{\mathrm{a}}$ & $200^{\mathrm{a}}$ & $193^{\mathrm{a}}$ & $199^{\mathrm{a}}$ & $228^{\mathrm{a}}$ & 12.8 & 0.001 \\
\hline $\mathrm{T} 3(\mathrm{ng} / \mathrm{dl})$ & $0.900^{c}$ & $1.17^{\mathrm{b}}$ & $1.02^{b}$ & $1.48^{\mathrm{a}}$ & $1.50^{\mathrm{a}}$ & $1.48^{\mathrm{a}}$ & $1.20^{\mathrm{ab}}$ & 0.081 & 0.001 \\
\hline $\mathrm{T} 4(\mathrm{ng} / \mathrm{dl})$ & $10.6^{\mathrm{c}}$ & $13.3^{\mathrm{b}}$ & $15.3^{\mathrm{a}}$ & $15.6^{\mathrm{a}}$ & $14.9^{\mathrm{a}}$ & $14.0^{\mathrm{ab}}$ & $15.0^{\mathrm{a}}$ & 0.041 & 0.001 \\
\hline $\operatorname{ALT}(\mathrm{U} / \mathrm{L})$ & $41.9^{\mathrm{a}}$ & $35.9^{\mathrm{b}}$ & $38.1^{\mathrm{b}}$ & $35.5^{\mathrm{b}}$ & $33.5^{\mathrm{b}}$ & $31.5^{\mathrm{b}}$ & $32.0^{\mathrm{b}}$ & 1.77 & 0.002 \\
\hline AST (U/L) & $62.3^{\mathrm{a}}$ & $62.3^{\mathrm{a}}$ & $56.8^{\mathrm{b}}$ & $56.5^{\mathrm{b}}$ & $58.0^{\mathrm{b}}$ & $57.5^{\mathrm{b}}$ & $59.5^{\mathrm{b}}$ & 10.0 & 0.001 \\
\hline Uric acid, & $2.87^{\mathrm{a}}$ & $2.14^{\mathrm{b}}$ & $2.03^{\mathrm{b}}$ & $1.99^{\mathrm{b}}$ & $2.11^{\mathrm{b}}$ & $2.09^{\mathrm{b}}$ & $1.98^{\mathrm{c}}$ & 0.970 & 0.002 \\
\hline Creatine & $0.880^{\mathrm{a}}$ & $0.571^{b}$ & $0.712^{\mathrm{b}}$ & $0.663^{\mathrm{b}}$ & $0.576^{\mathrm{b}}$ & $0.747^{\mathrm{b}}$ & $0.692^{\mathrm{b}}$ & 0.091 & 0.001 \\
\hline $\begin{array}{l}\text { Alkaline phosphatase } \\
\text { (U/100ml) }\end{array}$ & 12.6 & 11.3 & 11.6 & 13.6 & 11.3 & 13.0 & 12.0 & 1.59 & 0.09 \\
\hline Cholesterol (mg/dl) & $133^{\mathrm{a}}$ & $106^{\mathrm{b}}$ & $112^{\mathrm{b}}$ & $103^{b}$ & $100^{\mathrm{b}}$ & $101^{\mathrm{b}}$ & $117^{\mathrm{b}}$ & 6.96 & 0.004 \\
\hline Triglycerides & $80.4^{\mathrm{a}}$ & $68.3^{b}$ & $65.6^{\mathrm{b}}$ & $54.6^{\mathrm{b}}$ & $68.6^{\mathrm{b}}$ & $62.3^{\mathrm{b}}$ & $66.0^{\mathrm{b}}$ & 9.82 & 0.002 \\
\hline $\mathrm{HDL}(\mathrm{mg} / \mathrm{dl})$ & 54.3 & 54.0 & 57.7 & 56.6 & 66.9 & 48.9 & 59.1 & 4.72 & 0.086 \\
\hline $\mathrm{LDL}(\mathrm{mg} / \mathrm{dl})$ & $63.5^{\mathrm{a}}$ & $38.2^{\mathrm{b}}$ & $42.5^{b}$ & $36.5^{\mathrm{b}}$ & $21.0^{\mathrm{c}}$ & $30.9^{\mathrm{b}}$ & $45.0^{\mathrm{b}}$ & 4.30 & 0.003 \\
\hline
\end{tabular}

$\mathrm{a}, \mathrm{b}, \mathrm{c}$ Means in the same column followed by different letters are significantly different at $\mathrm{p} \leq$

0.05.SEM=Standard error of mean's. S .C = Saccharomyces cerevisiae with Se; S .S =Sodium Selenite; $\mathrm{HDL}=$ high-density lipoprotein; $\mathrm{LDL}=$ low-density lipoprotein ; $\mathrm{T} 3=$ triiodothyronine; $\mathrm{T} 4=$ thyroxine. 
Selenium source, Broiler, Performance, Blood parameters, Immune response

Table (6): Effect of different Selenium sources on plasma antioxidants enzymes of broiler chicks.

\begin{tabular}{|l|c|c|c|c|c|c|c|c|c|}
\hline \multicolumn{1}{|c|}{ Treatment } & Control & S.S & $\begin{array}{c}\text { SC- } \\
\text { Se.Zn }\end{array}$ & $\begin{array}{c}\text { Se- } \\
\text { Meth }\end{array}$ & $\begin{array}{c}\text { Se- } \\
\text { Glycine }\end{array}$ & $\begin{array}{c}\text { Se- } \\
\text { Yeast }\end{array}$ & SC & SEM & P value \\
\hline SOD(U/dl) & $201^{\mathrm{c}}$ & $221^{\mathrm{b}}$ & $251^{\mathrm{a}}$ & $247^{\mathrm{a}}$ & $251^{\mathrm{a}}$ & $250^{\mathrm{a}}$ & $251^{\mathrm{a}}$ & 1.39 & 0.001 \\
$\mathrm{GSH}(\mathrm{mg} / \mathrm{dl})$ & $957^{\mathrm{b}}$ & $969^{\mathrm{b}}$ & $984^{\mathrm{a}}$ & $985^{\mathrm{a}}$ & $988^{\mathrm{a}}$ & $989^{\mathrm{a}}$ & $983^{\mathrm{a}}$ & 1.28 & 0.002 \\
$\mathrm{GPX}(\mathrm{U} / \mathrm{dl})$ & $40.3^{\mathrm{b}}$ & $47.0^{\mathrm{a}}$ & $47.0^{\mathrm{a}}$ & $44.0^{\mathrm{a}}$ & $45.6^{\mathrm{a}}$ & $47.3^{\mathrm{a}}$ & $46.6^{\mathrm{a}}$ & 0.871 & 0.03 \\
$\mathrm{TAOC}(\mathrm{mMol} / \mathrm{dl}$ & $1.52^{\mathrm{b}}$ & $2.07^{\mathrm{a}}$ & $1.64^{\mathrm{ab}}$ & $1.78^{\mathrm{a}}$ & $1.82^{\mathrm{a}}$ & $2.07^{\mathrm{a}}$ & $1.87^{\mathrm{a}}$ & 0.121 & 0.001 \\
/dl) & & & & & & & & & \\
MDA(nmol/dl $)$ & $69.5^{\mathrm{a}}$ & $52.9^{\mathrm{b}}$ & $40.3^{\mathrm{c}}$ & $19.6^{\mathrm{d}}$ & $14.9^{\mathrm{d}}$ & $19.0^{\mathrm{d}}$ & $40.8^{\mathrm{c}}$ & 2.56 & 0.004 \\
\hline
\end{tabular}

a,b,c,d Means in the same row followed by different letters are significantly different at $\mathrm{p} \leq$ 0.05.SEM=Standard error of mean's. S .C = Saccharomyces cerevisiae with Se; S .S =Sodium Selenite; SOD =superoxide dismutase; GSH = glutathione; GPX =glutathione peroxidase; TAOC = total antioxidant capacity ;MDA= Malondialdehyde.

Table (7): Effect of different Selenium sources on blood plasma immune indices of broiler chicks.

\begin{tabular}{|l|c|c|c|c|c|c|c|c|c|}
\hline \multicolumn{1}{|c|}{ Treatment } & Control & S.S & $\begin{array}{c}\text { SC- } \\
\text { Se.Zn }\end{array}$ & $\begin{array}{c}\text { Se- } \\
\text { Meth }\end{array}$ & $\begin{array}{c}\text { Se- } \\
\text { Glycine }\end{array}$ & $\begin{array}{c}\text { Se- } \\
\text { Yeast }\end{array}$ & SC & SEM & P value \\
\hline PA (\%) & $18.0^{\mathrm{b}}$ & $23.3^{\mathrm{a}}$ & $23.3^{\mathrm{a}}$ & $21.0^{\mathrm{a}}$ & $22.3^{\mathrm{a}}$ & $22.6^{\mathrm{a}}$ & $22.6^{\mathrm{a}}$ & 0.863 & 0.006 \\
PI (\%) & $18.3^{\mathrm{c}}$ & $21.0^{\mathrm{b}}$ & $23.0^{\mathrm{a}}$ & $24.6^{\mathrm{a}}$ & $22.3^{\mathrm{a}}$ & $22.6^{\mathrm{a}}$ & $23.3^{\mathrm{a}}$ & 0.642 & 0.007 \\
LTT (\%) & $21.3^{\mathrm{c}}$ & $23.2^{\mathrm{b}}$ & $26.7^{\mathrm{a}}$ & $26.9^{\mathrm{a}}$ & $24.6^{\mathrm{ab}}$ & $25.3^{\mathrm{a}}$ & $26.3^{\mathrm{a}}$ & 0.45 & 0.001 \\
BA (\%) & $30.6^{\mathrm{b}}$ & $41.0^{\mathrm{a}}$ & $41.0^{\mathrm{a}}$ & $37.6^{\mathrm{a}}$ & $38.6^{\mathrm{a}}$ & $38.6^{\mathrm{a}}$ & $37.6^{\mathrm{a}}$ & 1.07 & 0.008 \\
LA (IU\%) & $10.6^{\mathrm{c}}$ & $11.0^{\mathrm{b}}$ & $12.3^{\mathrm{a}}$ & $12.8^{\mathrm{a}}$ & $13.0^{\mathrm{a}}$ & $12.0^{\mathrm{a}}$ & $12.6^{\mathrm{a}}$ & 0.512 & 0.001 \\
IgG(mg/100ml) & $65.3^{\mathrm{c}}$ & $72.7^{\mathrm{b}}$ & $76.7^{\mathrm{b}}$ & $81.3^{\mathrm{a}}$ & $85.4^{\mathrm{a}}$ & $71.9^{\mathrm{b}}$ & $78.3^{\mathrm{b}}$ & 0.796 & 0.003 \\
IgA(mg/100ml) & $33.4^{\mathrm{c}}$ & $53.7^{\mathrm{b}}$ & $81.3^{\mathrm{a}}$ & $60.6^{\mathrm{a}}$ & $69.6^{\mathrm{a}}$ & $79.3^{\mathrm{a}}$ & $80.6^{\mathrm{a}}$ & 4.45 & 0.008 \\
IgM(mg/100ml) & $18.4^{\mathrm{b}}$ & $54.1^{\mathrm{a}}$ & $53.0^{\mathrm{a}}$ & $31.6^{\mathrm{a}}$ & $30.0^{\mathrm{a}}$ & $35.5^{\mathrm{a}}$ & $53.6^{\mathrm{a}}$ & 2.71 & 0.001 \\
\hline
\end{tabular}

a,b,c Means in the same row followed by different letters are significantly different at $\mathrm{p} \leq$ 0.05.SEM=Standard error of mean's. S .C = Saccharomyces cerevisiae with Se; S .S =Sodium Selenite; $\mathrm{PA}=$ Phagocytic activity; $\mathrm{PI}=$ Phagocytic index; LA= lysozyme activity; $\mathrm{BA}=$ Bactericidal activity; LTT= Lymphocyte transformation test; IgA= Immunoglobulin A; IgG= Immunoglobulin $\mathrm{G}$; IgM= Immunoglobulin M.

\section{REFERENCES}

Abaza, M., 2002. Immune system and some physiological aspects in Japanese quail affected by antioxidants. Egyptian Poultry Science Journal, 22, 259-276.

Abou-Raya, A. K., \& Galal, A. G., 1971. Evaluation of poultry feeds in digestion trials with reference to some factors involved. J Anim Prod United Arab Repub.
Ahmad, H.; Tian, J.; Wang, J.; Khan, M.A.; Wang, Y.; Zhang, L. and Wang, T., 2012. Effects of Dietary Sodium Selenite and Selenium Yeast on Antioxidant Enzyme Activities and Oxidative Stability of Chicken Breast Meat. American Chemical Society. dx.doi.org/10.1021/jf3017207 | J. Agric. Food Chem. 2012, 60, 7111-7120. 
Amer, S. A., Omar A. E. and Abd ElHack M. E., 2018. Effects of selenium- and chromium-enriched diets on growth performance, lipid profile, and mineral concentration in different tissues of growing rabbits. Biol. Trace Elem. Rese., 12011-12018.

Ankur, K. and Baghel, R. P. S., 2011. Effect of different levels of dietary selenium on growth performance and nutrient utilization of broiler birds. Veterinary World, 4 : 173-175.

AOAC, 2004. Official methods of analysis. 18th ed., Association of Official Analytical Chemists, Washington, DC, USA.

Attia, Y. A.; Abdalah, A. A.; Zeweil, H. S.; Bovera, F.; Tag El-Din, A. A.; Araft, M. A., 2010. Effect of inorganic or organic selenium supplementation on productive performance, egg quality and some physiological traits of dual-purpose breeding hens. Czech J. Anim. Sci., 55, 2010 (11): 505-519.

Bakhshalinejad, R.; Hassanabadi, A.; Swick, R. A., 2019. Dietary sources and levels of selenium supplements affect growth performance, carcass yield, meat quality and tissue selenium deposition in broilers. Animal Nutrition,

https://doi.org/10.1016/j.aninu.2019.03 .003 .

Bakhshalinejad, R.; Kakhki, R. A. M. and Zoidis, E., 2018. Effects of different dietary sources and levels of selenium supplements on growth performance, antioxidant status and immune parameters in Ross 308 broiler chickens. British Poultry Science 10.1080/00071668. 2017.1380296.

Bartles, H.; Bohmer, M. and Heierli, C. 1972. Serum creatinine determination without protein precipitation. Clin. Chim. Acta 37: 193-197.

Bauer, J. D., 1982. Clinical laboratory methods, 9th edition, pp. 580-581. CV Mosby Co, USA.

Bianchi, A. T. J.; Moonen-Leusen, H. W. M.; van der Heijden, P. J. and Bokhout, B. A. 1995. The use of a double antibody sandwich ELISA and monoclonal antibodies for the assessment of porcine $\operatorname{IgM}, \operatorname{IgG}$, and IgA concentrations. Vet. Immunol. Immunopathol. 44:309-317.

Boostani, A.; Sadeghi, A. A.; Mousavi, S. N.; Chamani, M. and Kashan, N. 2015. Effects of Organic, Inorganic, and nano-Se on Growth Performance, Antioxidant Capacity, Cellular and Humoral Immune Responses in Broiler Chickens Exposed to Oxidative Stress. Livestock Science 178: $\quad 330-336 . \quad$ doi:10.1016/j. livsci.2015.05.004.

Bossuyt, X.; Lissoir, B.; Mariën, G.; Maisin, D.; Vunckx, J.; Blanckaert, N. and Wallemacq, P.2003. Automated Serum Protein Electrophoresis by Capillarys. Clin Chem Lab Med; 41(5):704-710.

Bunglavan, S. J.; Garg, A. K.; Dass, R. S. and Shrivastava, S. (2014). Effect of supplementation of different levels of selenium as nanoparticles/sodium selenite on blood biochemical profile and humoral immunity in male Wistar rats. Veterinary World, 7:1075-1081.

Cai, S. J.; Wu, C. X.; Gong, L. M.; Song, T.; Wu, H. and Zhang, L. Y. 2012. Effects of Nano-Selenium on Performance, Meat Quality, Immune Function, Oxidation Resistance, and Tissue Selenium Content in Broilers. Poultry Science 91: 2532-2539. doi:10.3382/ps.2012-02160. 
Selenium source, Broiler, Performance, Blood parameters, Immune response

Chen, G.; Wu, J. and Li, C. 2013. Effect of different selenium sources on production performance and biochemical parameters of broilers. Journal of Animal Physiology and Animal Nutrition 98(4):747-754.

Choct, M.; Naylor, A. J. and Reinke, N. 2004. Selenium supplementation affects broiler growth performance, meat yield and feather coverage. British Poultry Science, 45(5):677683.

Choupani, M.; Moghadam, O.Z.; Kelidari, H. R. and Ghazi, Sh. 2014 . influence of dietary selenium sources on thyroid hormone activation, tissue selenium distribution and antioxidant enzymes status in broiler chickens. trends in life sciences $3: 281-299$.

Chun, F. ; Bing, Y. and Daiwen, C. 2009. Effects of different sources and levels of selenium on performance, thyroid function and antioxidant status in stressed broiler chickens. International Journal of Poultry Science, 8: 583-587.

Dalto, D. B.; Roy, M.; Audet, I.; Palin, M. F.; Guay, F.; Lapointe, J. and Matte, J. J. 2015. Interaction between vitamin B6 and source of selenium on the response of the seleniumdependent glutathione peroxidase system to oxidative stress induced by estrus in pubertal pig. Journal of Trace Elements in Medicine and Biology, 32:21-29.

DengHua, Y. H.; Yuqing, L. and YongMig. 2001. Effects of immunoenhancement with selenium on immune function in chickens. Chinese J. Vet. Sci. Tech.21: 96-98.

Deniz, G.; Gezen, S. S. and Turkmen, I. I. 2005. Effects of two supplemental dietary selenium sources(mineral and organic) on broiler performance and drip-loss. Revue Med. Vet. 156: 423426.

Doumas, B. 1971. Colorimetric determination of serum albumin. Clin. Chim. Acta 31: 400-403.

Duncan, D. B. 1955. Multiple rang and Multiple F test. Biometrics, 11:1-42.

Ebeid, T. A.; Zeweil, H. S.; Basyony, M. M.; Dosoky, W. M. and Badry, H. 2013. Fortification of rabbit diets with vitamin $\mathrm{E}$ or selenium affects growth performance, lipid peroxidation, oxidative status and immune response in growing rabbits. Livestock Science 155: 323-331.

Edens, F. W. 2001. Involvement of SelPlex in Physiological Stability and Performance of Broiler Chickens. In: Science and Technology in the Feed Industry, Lyons, T.P. and K.A. Jacques (Eds.). Nottingham University Press, Nottingham, UK., pp: 349-376.

El-Deep, M. H.; Shabaan, M.; Assar, M. H.; Attia, Kh. M. and Sayed, M. A. M. 2017. Comparative Effects of Different Dietary Selenium Sources on ProductivePerformance, Antioxidative Properties And Immunity in Local Laying Hens Exposed to High Ambient Temperature. J. Animal and Poultry Prod., Mansoura Univ., 8 (9): $335-343$.

Ellman, G. L. 1959. Tissue sulfhydryl groups. Arch. Biochem. Biophys., 82: 70-77.

EL-Sebei, A. 2000. Influence of selenium and vitamin $\mathrm{E}$ as antioxidants on immune system and some physiological aspects in broiler chickens. Egyptian Poultry Science Journal, 20, 1065-1082.

El-Sheikh, A. M. H.; Abdalla, E. A. and Hanafy, M. M. 2010. The effect of organic selenium supplementation on productive and physiological 


\section{A. A-Ghazalah ${ }^{\mathbf{1}}$ et al.}

performance in a local strain of chicken. 2-immune system and some physiological aspects in bandarah chicks affected by organic selenium. Egypt. Poult. Sci. Vol (30) (ii): (517533).

Engstad, R. E.; Robertsen, B. and Frivold, E. 1992. Yeast glucan induces increase in lysozyme and complementmediated haemolytic activity in Atlantic salmon blood. Fish and Shellfish Immun. 2: 287 - 297.

FDA. 2000. FDA approves food additive petition for selenium yeast. Page 10 in FDA Veterinarian Newsletter (July/August). U. S. Food and Drug Administration, Washington, D.C.

Ferit, M. G.; Sahin, N. and Kucuk, O. 2003. Effects of vitamin $E$ and selenium on thyroid status, adrenocorticotropin hormone, and blood serum metabolite and mineral concentrations of Japanese quails reared under heat stress $\left(34^{\circ} \mathrm{C}\right)$. Journal of Trace Element in Experimental Medicine, 16:95-104.

Fisinin, V. I.; Papazyan, T. T. and Surai, P. F. 2008. Producing specialist poultry products to meet human nutrition requirements: Selenium enriched eggs. World's Poult Sci J. 64:85-98.

Fossati, P. and Prencipe, L. 1982. Serum triglycerides determined colorimetrically with an enzyme that produces hydrogen peroxide Clin. Chem. 28: 2077-2080.

Friedewald, W. T.; Levy, R. T. and Frederickson, D. S.1972. Estimation of the concentration of low-density lipoprotein cholesterol in plasma without use of the preparative ultracentrifuge. Clin. Chem. 18: 499502.
Gajčević, Z.; Kralik, G.; Has-Schön E. and Pavić, V. 2009. Effects of organic selenium supplemented to layer diet on table egg freshness and selenium content. Italian Journal Animal Science 8, 189-199.

Göçmen, R.; Yazgan, O.; and Cufadar, Y. 2016. Effect Of Different Organic And Inorganic Selenium Levels On Performance, Selenium Concentrations Of Some Tissues, Glutathione Peroxidase Enzyme Activity And Meat Quality In Broilers. The Journal of Animal \& Plant Sciences, 26(4): 2016, Page: 916-923 ISSN: 10187081.

Hanafy, M. M.; El-Sheikh, A. M. H. and Abdalla, E. A. 2009. The effect of organic selenium supplementation on productive and physiological performance in a local strain of chicken.1The effect of organic selenium (Sel-Plex) on productive, reproductive and physiological traits of Bandarah local strain. Egypt Poult Sci. 29:1061-1084.

Haug, A.; Eich-Greatorex, S.; Bernhoft, A.; Wold, J. P.; Hetland, H.; Christophersen, O. A. and Song, T. 2007. Effect of dietary selenium and omega-3 fatty acids on muscle composition and quality in broilers. Lipids Health Dis. 6: 29-37.

Hegazy, S. M. and Adachi, Y. 2000. Comparison of the effects of dietary selenium, zinc, and selenium and zinc supplementation on growth and immune response between chick groups that were inoculated with Salmonella and aflatoxin or Salmonella. Poult. Sci. 78:331-335.

Henry, R.; Cannon, D. and Winkelman, J. 1974. Clinical chemistry, principles and techniques, 
Selenium source, Broiler, Performance, Blood parameters, Immune response

$2^{\text {nd }}$ edition, Harper and Row, New York, USA

Ibrahim, D.; Kishawy, A. T. Y.; Khater, S. I.; Arisha, A. H.; Mohammed, H. A.; Abdelaziz, A. Sh.; Abd El-Rahman, Gh. I. and Elabbasy, M. Th. 2019. Effect of Dietary Modulation of Selenium Form and Level on Performance, Tissue Retention, Quality of Frozen Stored Meat and Gene Expression of Antioxidant Status in Ross Broiler Chickens. Animals, 9, 342; doi:10.3390/ani9060342.

Ibrahim, M. T.; Eljack, B. H. and Fadlalla. I. M. T. 2011. Selenium supplementation to broiler diets. Anim. Sci. J. 2:12-17.

Invernizzi, G.; Agazzi, A.; Ferroni, M.; Rebucci, R.; Fanelli, A.; Baldi, A.; Dell'Orto, V. and Savoini, G. 2013. Effects of inclusion of seleniumenriched yeast in the diet of laying hens on performance, eggshell quality and selenium tissue deposition. Ital $\mathbf{J}$ Anim Sci. 1:1-8.

Kawahara, E.; Ueda, T. and Nomura, S. 1991. In vitro phagocytic activity of white spotted shark cells after injection with Aermonas salmonicida extracellular products. Gyobo kenkyu, Japan 26: 213-214.

Koracevic, D.; Koracevic, G.; Djordjevic, V.; Andrejevic, S. and Cosic, V. 2001. Method for the measurement of antioxidant activity in human fluids. J. Clin. Pathol., 54: 356361.

Li, J. L.; Zhang, L.; Yang, Z. Y.; Zhang, Z. Y.; Jiang, Y.; Gao, F. and Zhou, G. H. 2017. Effects of Different Selenium Sources on Growth Performance, Antioxidant Capacity and Meat Quality of Local Chinese
Subei Chickens. Biol Trace Elem Res., 181:340-346.

Ljubic, B.; Milinkovic-Tur, S.; Pirsljin, J.; Zdelar-tuk, M. and Filipovic, N. 2006. Effect of organic selenium food supplementation and fasting on adipose tissue lipid concentration and lipoprotein lipase activity in broiler chickens. In: Proceeding of European Poultry Conference. Verona, Italy.

Lopez-Virella, M.F.; Stone, S.; Eills, S. and Collwel, J.A. 1977. Determination of HDL-cholesterol using enzymatic method. Clin. Chem. 23: 882-884.

Madkour, M.; Ali, H. M.; Yassein, S. A.; Abdel-Fattah, S. A.; El-Allawy, H. M. and El-Wardany, I. 2015. Effect of dietary organic selenium supplement on growth and reproductive performance of Japanese quail breeders and their progeny and its relation to antioxidation and thyroid activity. International Journal of Poultry Science, 14:317-324.

Madron, P. and Vrzgulova, N. 1988. Vitamin $\mathrm{E}$ and selenium increase the natural resistance of farm animals. Veterinarstvi. 38: 369-371.

Meng, T.; Liu, Y.; Xie, C.; Zhang, B.; Huang, Y.; Zhang, Y.; Yao, Y.; Huang, R.; Wu, X. 2019. Effects of Different Selenium Sources on Laying Performance, Egg Selenium Concentration, and Antioxidant Capacity in Laying Hens. Biological Trace Element Research 189:548555. https://doi.org/10.1007/s12011018-1490z.

Mikulski, D.; Jankowski, J.; Zduńczyk, Z.; Wróblewska, M.; Sartowska, K. and Majewska, T. 2009. The effect of selenium source on performance, carcass traits, oxidative status of the organism, and meat 
quality of turkeys. Journal of Animal and Feed Sciences, 18, 2009, 518-530.

Misra, H. P. and Fridovich, I. 1972. The role of superoxide anion in the autoxidation of epinephrine and a simple assay for superoxide dismutase. J. Biol. Chem. 247: 3170-3175.

Moslehi, H.; Navidshad, B.; Sharifi, S. D. and Aghjegheshlagh, F. M. 2019. Effects of selenium and flaxseed on selenium content and antioxidant properties of eggs and immune response in hens. South African Journal of Animal Science , 49 770$780 \quad$ (No. 4 ). http://dx.doi.org/10.4314/sajas.v49i4.1 $\underline{9}$.

Naik, S. k. 2012. Studies on dietary supplementation of selenium and vitamin-e on growth performance and Immunological response in vencobb broiler chicken. Thesis M. Sc. department of animal nutrition college of veterinary science and animal husbandry anjora.

National Academic Press, Washington, DC.

National Research Council, NRC, 1994. Nutrient Requirements of Poultry. 9th Edn.

Niu, Z. Y.; Liu, F. Z.; Yan, Q. L. and Li, L. 2009. Effects of different levels of selenium on growth performance and immunocompetence of broilers under heat stress. Arch Anim Nutr. 63:56-65.

Okunlola, D. O.; Akande, T. O. and Nuga, H. A. 2015. Hematological and serum characteristics of broiler birds fed diets supplemented with varying levels of selenium powder. Journal of Biology, Agriculture and Healthcare, 5:107-110.

Oliveira, T. F. B.; Rivera, D. F. R.; Mesquita, F. R.; Braga, H.; Ramos,
E. M. and Bertechini, A. G. 2014. Effect of different sources and levels of selenium on performance, meat quality, and tissue characteristics of broilers. J. Appl. Poult. Res. 23 :15-22.

Paglia, D. E. and Valentine, W. N. 1967. Studies on the quantitative and qualitative characterization of erythrocyte glutathione peroxidase. J Lab Clin Med , 70(1):158-169.

Pappas, A. C.; Acamovic, T.; Sparks, N. H. C.; Surai, P.F. and McDevitt, R. M. 2005. Effects of supplementing broiler breeder diets with organic selenium and polyunsaturated fatty acids on egg quality during storage. Poult. Sci. 84:865-874.

Payne, R. L. and Southern, L. L. 2005b. Changes in glutathione peroxidase and tissue selenium concentrations of broilers after consuming a diet adequate in selenium. Poult. Sci. 84(8):1268-76.

Payne, R. L.; and Southern, L. L. 2005a. Comparison of inorganic and organic selenium sources for broilers. Poult. Sci. 84 (6):898-902.

Peric, L.; Milosevic, N.; Zikic, D.; Kanacki, Z.; Dzinic, N.; Nollet, L. and Spring, P. 2009. Effect of selenium sources on performance and meat characteristics of broiler chickens. Journal of Applied Poultry Research, 18:403-409.

Preter, F. S. 2000. Organic selenium : benefits to animal and human, a biochemist's view. In: Proceedings of Alltech's $16^{\text {th }}$ symposium. Nottingham University Press, Nottingham, pp: 205-2013.

Ramezani, S.; Riasi, A.; Afzali, N. and Fathi Nasari, M. H. 2011. Effect of selenium and sodium bicarbonate supplementationdiets on blood 
Selenium source, Broiler, Performance, Blood parameters, Immune response

biochemical properties, growth

performance and carcass traits of broilers in heat stress condition. Agricultural Scientific Information and Documentation Centre, Agricultural Research and Education Organization, Iran.

Rao, S. V. R.; Prakash, B.; Raju, M. V. L. N.; Panda, A. K.; Poonam, S. and Murthy, O. K. 2013. Effect of Supplementing Organic Selenium on Performance, Carcass Traits, Oxidative Parameters and Immune Responses in Commercial Broiler Chickens. Asian-Aust. J. Anim. Sci. Vol. 26, No. 2 : 247-252. doi:10.5713/ ajas.2012.12299.

Reitman, S. and Frankel, S. 1957. A Method for determination of enzymatic activities. Am. J. Clin. Path., 287: 56-58.

Salman, M.; Selcuk, Z. and Muglali, O. H. 2007. Effect of vitamin $E$ and selenium on performance, plasma and tissue GSH-Px activity in broilers. J. Istanbul Vet. Sci. 3: 25-34.

SAS Institute 2002. SAS/STAT User's guide statistics. SAS institute INC., Cary. NC, USA.

Schrauzer, G. $\quad$ N. 2000. Selenomethionine: A review of its nutritional significance, metabolism, and toxicity. J. Nutr. 130:1653-1656.

Selim, N.A.; Radwan, N.L.; Youssef, S.F.; Eldin, T.S. and Elwafa, S.A. 2015.Effect of inclusion inorganic, organic or nano selenium forms in broiler diets on: 2-Physiological, immunological and toxicity statuses of broiler chicks. Int. J. Poult. Sci. 14, 144.

Sevcikova, S.; Skrivan, M.; Dlouha, G. and Koucky, M. 2006. The effect of selenium source on the performance and meat quality of broiler chickens.

Czech J. Anim. Sci. 51: 449-457.

Srimongkol, C. 2003. Effects of selenium supplementation on growth performance, thyroid hormone (T3) Levels, antioxidant enzyme and disaccharidase activities in broiler chicks. Thesis M.Sc. Chulalongkorn University.

Stein, E. A. 1986. Quantitative enzymatic colorimetric determination of total cholesterol in serum or plasma. In: Textbook of Clinical Chemistry. N. W. Tietz, editor. WB. Saunders, Philadelphia, USA Pp. 879-886.

Sundu, B.; Adjis, A. and Hatta, U. 2019. Effect of Addition of Selenium from Different Feedstuffs on Feed Digestibility, Growth Performance, Carcass Percentage and Meat Selenium of Broiler Chickens. Int. J. Poult. Sci., 18 (5): 208-213.

Trinder, P. 1969. Enzymatic colorimetric determination of glucose in serum, plasma or urine. Ann. of Clin. Biochem. 6: 24-26.

Upton, J. R.; Edens, F. W. and Ferket, P. R. 2008. Selenium yeast effect on broiler performance. International Journal of Poultry Science 7: 798-805.

Wang, Y. B. and Xu, B. H. 2008. Effect of different selenium source (sodium selenite and selenium yeast) on broiler chickens.Animal Feed Science and Technology, 144:306-314.

Wang, Y. X.; Zhan, X. A.; Zhang, X. W.; Wu, R. J. and Yuan, D. 2011. Comparison of Different Forms of Dietary Selenium Supplementation on Growth Performance, Meat Quality, Selenium Deposition, and Antioxidant Property in Broilers Biol Trace Elem Res 143:261-273.

Wu, R.; Zhan, X.; Wang, Y.; Zhang, X.; Wang, M. and Yuan, D. 2011. 
Effect of different selemethionine forms and levels on performance of breeder hens and se distribution of tissue and egg inclusion. Biol Trace Elem Res. 143:923-931.

Yang, Y. R.; Meng, F. C.; Wang, P.; Zheng, Q. H.; Jiang, Y. B.; Yin, Q. Q.; Chang, J.; Zuo, R. Y.; and Liu, J. X. 2012. Effect of organic and inorganic selenium supplementation on growth performance, meat quality and antioxidant property of broilers. African Journal of Biotechnology Vol. 11(12), pp. 3031-3036.

Yoon, I.; Werner, T. M. and Butler, J. M. 2007. Effect of Source and Concentration of Selenium on Growth Performance and Selenium Retention in Broiler Chickens. 2007 Poultry Science 86:727-730.

Zamani Moghaddam, A.; Mehraei Hamzekolaei, M.; Khajali, F. and Hassanpour, H. 2017. "Role of Selenium from Different Sources in Prevention of Pulmonary Arterial Hypertension Syndrome in Broiler Chickens." Biological Trace Element Research 176: 1-7.

Zeweil, H. S. 1996. Enzyme supplements to diets growing Japanese quails. Egypt. Poult. Sci. J., 16: 535-557.

Zhang, Y.; Suzhen, Z.; Wang, X.; Chunyang, W. and Fuchang, $L$. 2011. The effect of dietary Selenium levels on growth performance, antioxidant capacity and glutathione peroxidase 1(GSHPx1) mRNA expression in growing meat rabbits. Anim.Feed Sci.Technol.,169, 259-264.

Zhang, Z. W.; Wang, Q. H.; Zhang, J. L.; Li, S.; Wang, X. L. and Xu, S. W. 2012. Effects of oxidative stress on immunosuppression induced by selenium deficiency in chickens. DOI 10.1007/s12011-012-9439-0.

Zhou, X. and Wang, Y. 2011. "Influence of Dietary Nano Elemental Selenium on Growth Performance, Tissue Selenium Distribution, Meat Quality, and Glutathione Peroxidase Activity in Guangxi Yellow Chicken." Poultry Science 90: 680-686. doi:10.3382/ps.2010-00977.

Zia, M. W.; Khalique, A.; Naveed, S. and Hussain, J. 2016. Impact of selenium supplementation on productive performance and egg selenium status in native Aseel chicken. Italian Journal of Animal Science, $\quad 15: 4, \quad 649-657$, DOI: 10.1080/1828051X.2016.1222247.

Zia, W. M.; Khalique, A.; Naveed , S.; Hussain, J.; Muhammad, I.; Khan T. M. and Rehman Sh. M. 2017a. Exploring the effect of selenium forms

Zia, W. M.; Khalique, A.; Naveed, S.; Hussain, J. and Muhammad, I. 2017b. Effect of selenium supplementation on glutathione peroxidase (GPX), cholesterol, thyroxin (T4) and other blood biochemicals in local Aseel. Indian J. Anim. Res., 51 (6): 1051-1056. 


\title{
الملخص العربي
}

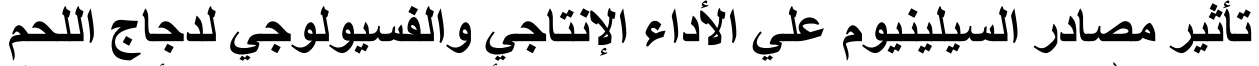

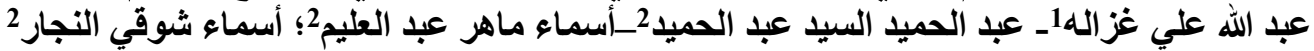

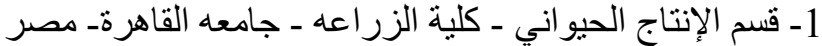

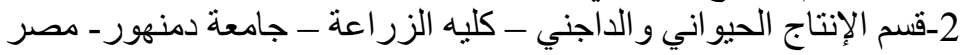

أجريت هذه الدراسة في وحدة بحوث الدو اجن بمزرعة البستان ، قسم الإنتاج الحيواني و الداجني، كلية الزراعة

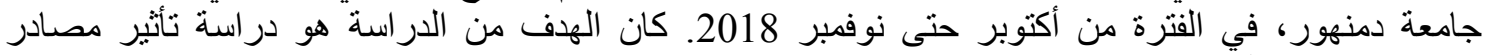

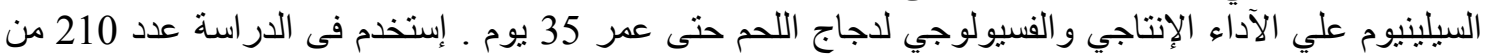

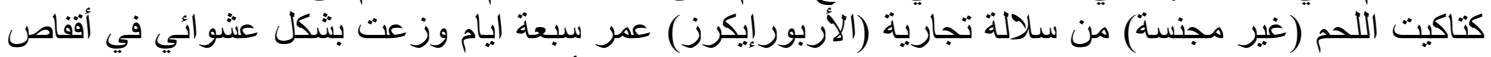

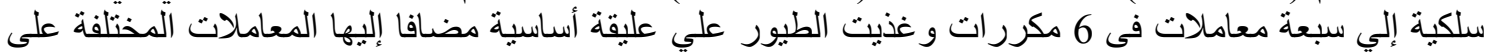

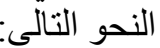

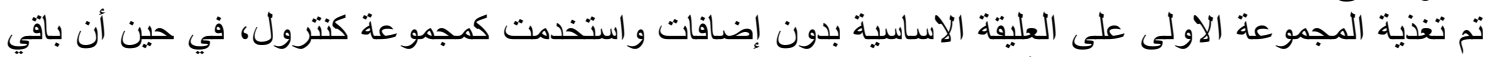

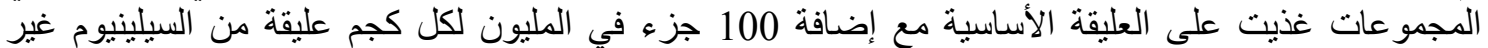
العضوى (سيلينوم سلينات) وكذلك صور مختلفة من السيلينيوم العضوي (سيلينيوم زنك مع الكيونة الخميرة - سيلينيوم

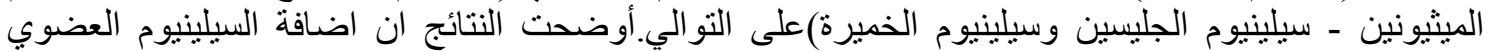

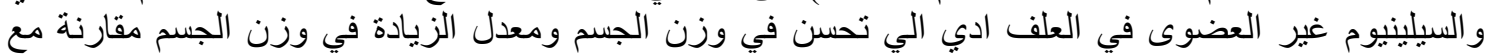

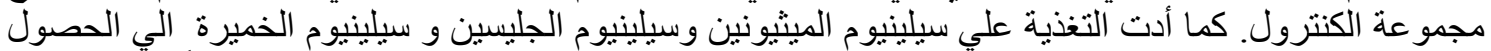

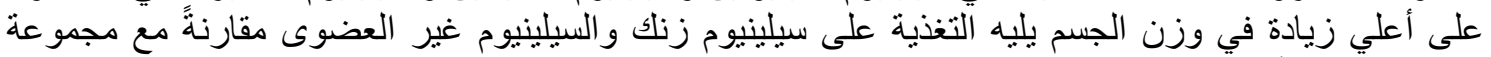

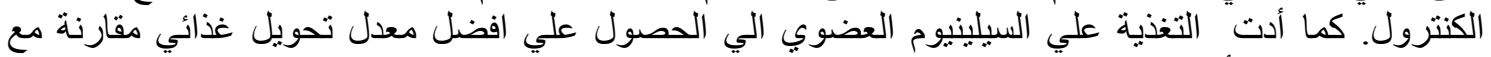

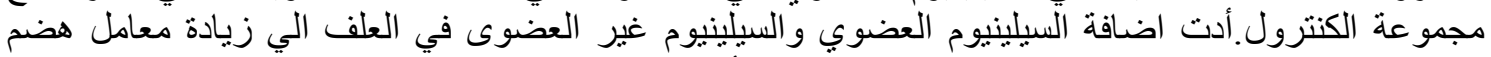

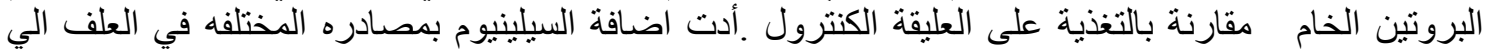

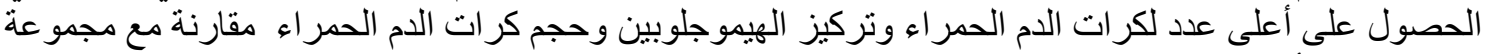

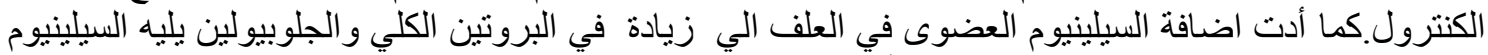

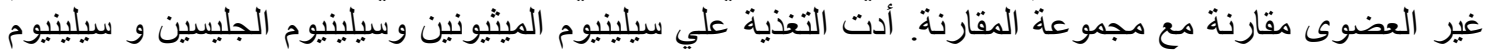

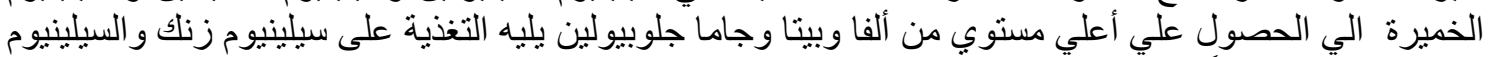

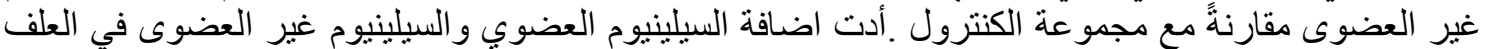

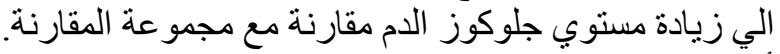

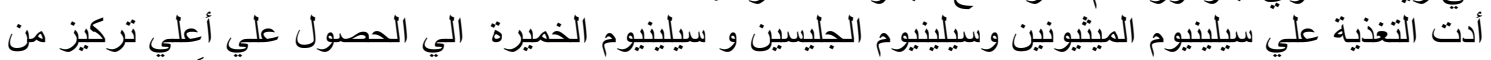

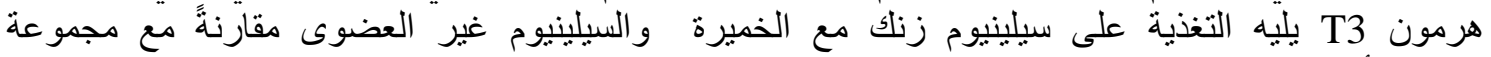

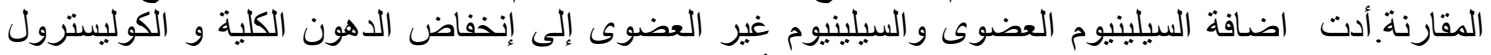

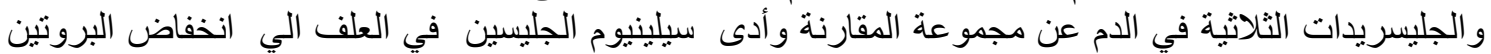

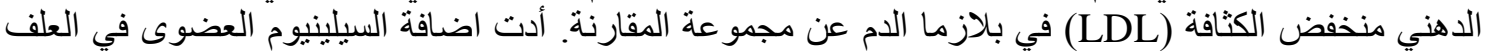

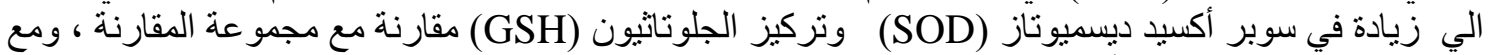

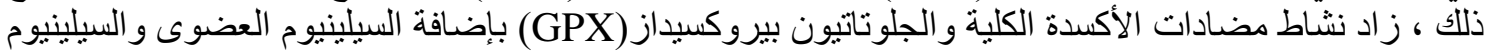
غير العضوى.أدت اضافة السيلينيوم العضوى والسيلينيوم غير العضوى الي زيادة في PA ,BA, IgM مقارنة مع مجمو عة المقارنة.

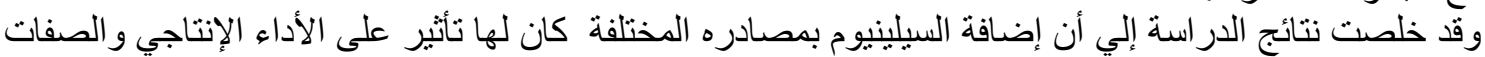

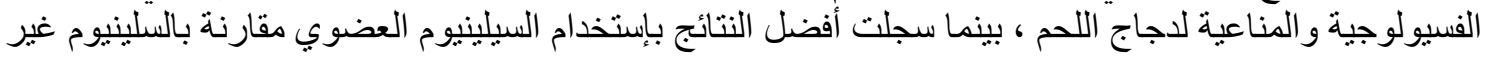

